Louisiana State University LSU Digital Commons

Faculty Publications

Department of Geography \& Anthropology

2015

\title{
Sixteenth-century soil carbon sequestration rates based on Mexican land-grant documents
}

Andrew Sluyter

Louisiana State University, asluyter@lsu.edu

Richard Hunter

Follow this and additional works at: http://digitalcommons.lsu.edu/geoanth_pubs

\section{Recommended Citation}

Sluyter, Andrew and Hunter, Richard, "Sixteenth-century soil carbon sequestration rates based on Mexican land-grant documents" (2015). Faculty Publications. 5.

http://digitalcommons.lsu.edu/geoanth_pubs/5

This Article is brought to you for free and open access by the Department of Geography \& Anthropology at LSU Digital Commons. It has been accepted for inclusion in Faculty Publications by an authorized administrator of LSU Digital Commons. For more information, please contact gcoste1@lsu.edu. 


\title{
Sixteenth-century soil carbon sequestration rates based on Mexican land-grant documents
}

\author{
Richard Hunter' and Andrew Sluyter ${ }^{2}$
}

\begin{abstract}
A significant gap in our understanding of global change involves the linkages between historical land-use and land-cover change (LULCC), Holocene terrestrial carbon (C) pool fluxes, and climate change. To address that research problem, this method uses land grants for sheep ranches awarded in early colonial (I52 I-I620 CE) Mexico to quantify the amount of land converted from cropland to pastureland. Soil is the largest terrestrial C pool, and converting cropland to pastureland significantly increases soil $C$ sequestration rates, thereby reducing atmospheric $C$. The land grants and associated archival documents contain location-specific information about soils, vegetation, hydrology, and other variables that make it possible to map the ranches in a Geographic Information System (GIS) and quantify LULCCs and terrestrial C pools over time and space. The results demonstrate the utility of such archival documents to research on Holocene global change, indicate that LULCC during Mexico's colonial period increased the region's soil C sequestration rate, and confirm previous research that has suggested that transformations associated with European colonization of the Americas acted as an anthropogenic contributor to the period of moderate cooling known as the 'Little Ice Age' (I550-I850 CE).
\end{abstract}

\section{Keywords}

climate change, GIS, 'Little Ice Age', Mexico, Neotropics, soil carbon sequestration

Received 20 October 2014; revised manuscript accepted 21 December 2014

\section{Introduction}

The influence of pre-industrial land-use and land-cover change (LULCC) on the global climate system is becoming more clearly understood (He et al., 2014; Ruddiman, 2003; Ruddiman et al., 2014). Many conclusions are based on global-scale models that calculate change in the extent of cropland and pasture using historically reconstructed population densities as the independent variable (Boyle et al., 2011; Kaplan et al., 2011; Klein Goldewijk et al., 2011; Pongratz et al., 2008). Wide disagreement among these models because of differing demographic assumptions and lack of agroecological specificity has resulted in more attention to empirical LULCC research (Ellis, 2011; Yan et al., 2013). One source of data has been sedimentary charcoal records from lake and wetland cores, but their interpretation has likewise led to disagreement. For example, some have argued that sedimentary charcoal records for the Neotropics demonstrate less forest clearance through burning as indigenous populations collapsed beginning in 1492, forest regeneration through the 19th century, and increased terrestrial carbon (C) sequestration that contributed significantly to the period of atmospheric cooling known as the 'Little Ice Age' (1550-1850 CE; Dull et al., 2010; Nevle and Bird, 2008; Nevle et al., 2011). Others, in contrast, have interpreted the sedimentary charcoal record as demonstrating that biomass burning and atmospheric $\mathrm{C}$ levels had already begun to decline before 1492, and cannot therefore be ascribed to European colonization of the Americas, and that the 'Little Ice Age' actually forced LULCC in the Americas (Power et al., 2012).

One approach to improving interpretation of both the models based on demographic data and empirical data such as sedimentary charcoal involves the use of LULCC data systematically collected by colonial officials over extensive areas and now preserved as landgrant documents in archives. This research uses land grants awarded in an area of central Mexico in the 16th and 17th centuries to reconstruct LULCC, to estimate associated soil C sequestration rates, and to relate them to climate change. The study area is the southeastern quarter of the Valle del Mezquital, a semi-arid tropical highland where New Spain's viceroys awarded 47 sheep ranches between 1535 and 1610 . Its colonial land grants and associated archival documents contain location-specific information about the sites of the grants that include eyewitness observations of soils, vegetation, hydrology, previous habitations, and other LULCC variables. Descriptions of landmarks and boundaries allow the land grants to be relocated and mapped in a Geographic Information System (GIS) to quantify LULCCs and terrestrial C pools over time and space.

\section{Study area}

The southeastern Valle del Mezquital is a semi-arid basin of $\sim 700 \mathrm{~km}^{2}$ located in the highlands of central Mexico, just north

'State University of New York College at Cortland, USA

${ }^{2}$ Louisiana State University, USA

\section{Corresponding author:}

Richard Hunter, State University of New York College at Cortland, I38 Old Main, Cortland, NY 13045, USA.

Email: richard.hunter@cortland.edu 


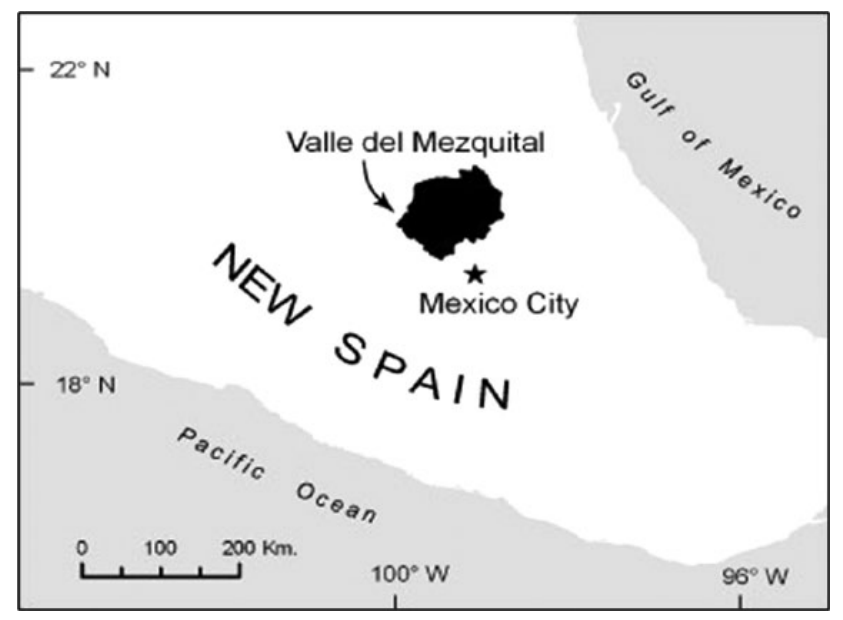

Figure I. Central Mexico and the Valle del Mezquital.

of Mexico City (Figure 1; Hunter, 2010). Extreme land degradation, quite evident to even a casual observer, is a defining characteristic of the entire Valle del Mezquital (Figure 2). In some places, gullying and unchecked sheet erosion have turned once vegetated slopes into wastelands representative of major degradation of Earth's 4.5 million $\mathrm{km}^{2}$ of tropical highlands (Hughes, 2001; Nyssen et al., 2009; Richards, 2003). The causes and timing of that soil erosion remain controversial, with some blaming precolonial agricultural practices (Cook, 1949), others overgrazing by sheep during the first century of the colonial period (1521-1620; Melville, 1994), others agricultural modernization during the late colonial and early postcolonial periods (Butzer, 1992, 1993, 1996), and yet others a more complex process related to the cessation of maintenance of extensive systems of precolonial terracing during the demographic collapse of the 16th century (Hunter, 2009).

By late precolonial times (1400-1521), the basin was densely settled, with irrigated fields along valley bottoms and semi-terraces stepping up hillsides (Gerhard, 1993; Hunter, 2009; Mastache and Cobean, 2001; Melville, 1994). Warfare, epidemic diseases, and colonization caused a demographic collapse similar to elsewhere in the Americas during the first century of colonization, with sudden population decline, abandonment of cropland, deterioration of canals and terraces, and awards of emptied lands to Spaniards and indigenous communities to use as sheep pasture (Hoekstra, 1992; Hunter, 2009, 2014; Prem, 1992). During the remainder of the colonial period (1621-1810) and the early postcolonial period (1810-1910), sheep ranching and agave cultivation became the principal land uses (De Mendizábal, 1947; Fournier-García and Mondragón, 2003; Hernández Mogica, 2000; Johnson, 1977; Konrad, 1980). The soil erosion that characterizes the Valle del Mezquital came to serve as an emblem of land degradation, rural poverty, and out-migration characteristic of so much of Mexico. Since early in the 20th century, untreated storm runoff and sewage water has flowed northward from Mexico City through a complex system of canals, tunnels, and reservoirs to irrigate roughly 90,000 ha of rehabilitated agricultural fields, albeit with health risks for the local population and urban markets that consume the produce (Luchano-Constantino et al., 2009; Ortega-Larrocea et al., 2001; Tortajada and Castelán, 2003).

\section{Materials and methods}

In 1521, Spanish Conquistadors captured the Aztec capital Tenochtitlán and established the colony of New Spain, roughly equivalent to present-day Mexico. In the 1530s, with demand growing for hides, tallow, meat, and wool, colonists and native

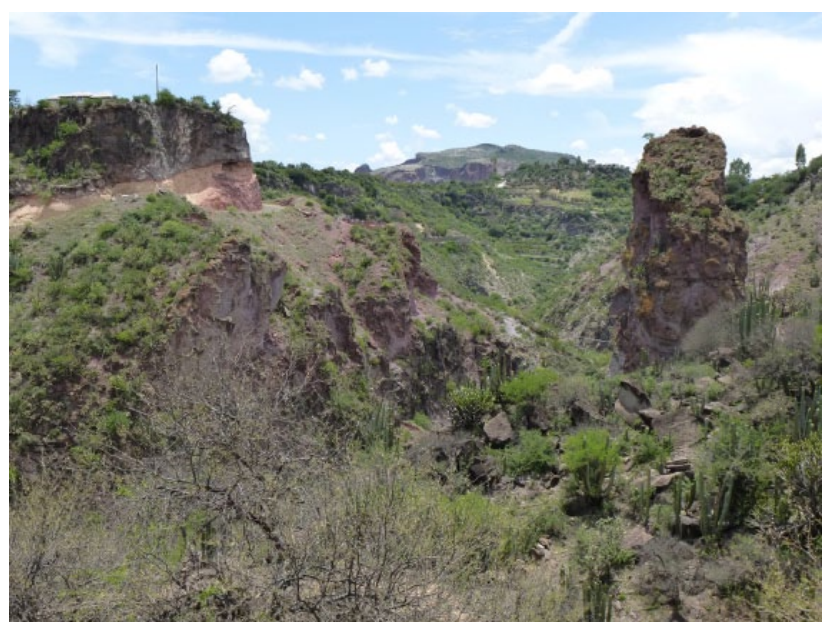

Figure 2. Soil pedestals, a deeply incised streambed, and arid-zone spiny vegetation near Tecozautla, Hidalgo, Mexico, July 2013. Source: Photo by Richard Hunter.

communities alike increasingly sought titles for livestock ranches. Throughout much of the early colonial period, the viceroys of New Spain awarded land grants for various land uses: agriculture, lime kilns, and ranching. The colonial land-grant register is now preserved in the Archivo General de la Nación in Mexico City (Sluyter, 2002). The associated site descriptions allow many land grants to be relocated and mapped using GIS (Hunter, 2010). These maps then facilitate area calculations of LULCCs over time and space for an entire century.

In general, as detailed in the literature, the land grants contain the awardee's name, the name of the jurisdiction where the ranch was to be sited, a description of the site intended to reduce ambiguity about its borders, and the calendar date the grant was notarized by the scribe in Mexico City (Hunter, 2009, 2014; Hunter and Sluyter, 2011; Sluyter, 1999, 2002). The land grants for sheep ranches also stipulate a north-south oriented square of 776 ha and a stocking rate of 2000 head as the minimum necessary to retain grant ownership (Hunter, 2010). The site descriptions vary greatly in detail and may reference conspicuous landscapes features such as large trees or waterholes, toponyms of nearby settlements or mountains, the names of adjacent landowners, roads and stock trails, streambeds and whether they carry water, and vegetation and soil characteristics.

Overall, mapping ranches distributed in land grants yields a locationally and temporally precise, spatially extensive, fairly contiguous set of eyewitness descriptions of an area's landscape over the course of several decades. These maps temporally cover the critical transitional century from precolonial to colonial land uses (1520s-1620s) and the onset of the 'Little Ice Age'. The coverage of the grants clearly must be biased in favor of areas supporting at least some grassland, that resource being what prospective ranchers sought. Yet, despite that caveat, the grants do cover extensive portions of Mexico and by definition cover the lands that would have been turned into pastureland. As another caveat, informal grazing might have impacted the vegetation of a particular site before a rancher obtained a grant to it, but the land inspector's descriptions are contemporaneous with the major influx of livestock in any particular district within a region and thus describe its LULCC over the course of several decades of ranch expansion. As a general principle, then, if the earliest land grants in a district describe intact vegetation cover and land grants awarded several decades later that occupy the interstices among existing ranches in that same district continue to describe intact vegetation cover, the conclusion must be that introduced livestock did not degrade the land. If the later grants describe soil erosion and vegetation degradation in comparison with the earlier ones, 


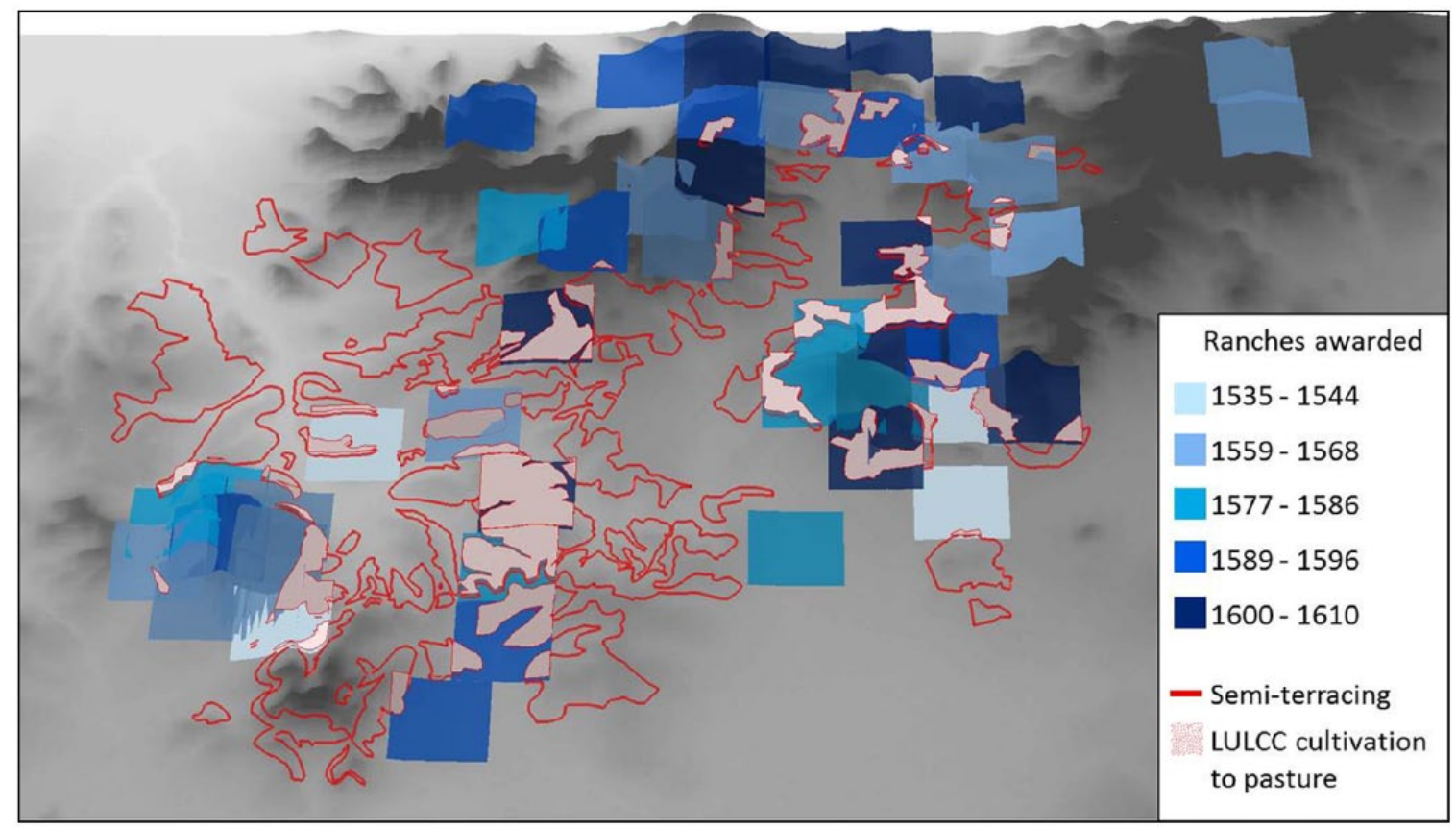

Figure 3. Screenshot of GIS showing overlap between sheep ranches and agricultural semi-terraces.

the conclusion must be that livestock, perhaps in concert with climate changes and other factors, did contribute to that transformation. The role of climate versus humans and their livestock can be further distinguished by applying the method to a large enough area to discriminate between local-scale LULCC caused by ranching and regional-scale LULCC caused by climate change.

Through a combination of field and archival research, the ranches can be mapped in a GIS (Hunter, 2010, 2014). This approach permits the reconstruction of spatio-temporal patterns of LULCC that occurred in the study area during the first century of colonization as the native population collapsed and cropland was converted into pastureland, as also occurred in other parts of New Spain. The quantifiable LULCCs over time, together with the different rates of soil $\mathrm{C}$ sequestration between these types, permits the calculation of changes in the study area's total soil $\mathrm{C}$ sequestration over nearly a century.

Soil is the largest terrestrial $\mathrm{C}$ pool, and numerous studies and meta-analyses confirm that converting cropland to pastureland significantly increases soil organic C (SOC) sequestration rates (Don et al., 2011; Guo and Gifford, 2002; Johnson, 1992; Post and Kwon, 2000). This increase occurs because after tillage ceases, SOC is not as readily oxidized and lost to the atmosphere through $\mathrm{CO}_{2}$ emissions. In Central Mexico's tropical dry-forest biome, the total $\mathrm{C}$ pool (above- and belowground biomass and soil) of a pasture is $31 \%$ larger than that of a cultivated field: 108.3 Megagrams $(\mathrm{Mg}) \mathrm{Cha}^{-1}$ and 82.7 $\mathrm{MgC} \mathrm{ha}^{-1}$, respectively (Jaramillo et al., 2003; Ordóñez et al., 2008). This figure is only slightly outside the well-established, more general range of $25-30 \%$ SOC loss following cultivation (Houghton et al., 2012). Because precolonial farmers in Mexico did not use plows, such modern estimates might somewhat inflate the differences in SOC between cropland and rangeland during the 16th-century transition from precolonial to colonial agroecologies.

\section{Results}

In this initial test of that method, 44 land grants awarded between 1535 and 1610 were mapped in a GIS (Figure 3). These land grants established 47 sheep ranches (three of the grants awarded two ranches each). They were all awarded within six cabeceras, colonial administrative districts with identically named head towns: Apaxco, Hueypoxtla, Tequixquiac, Tezcatepec, Tlapanaloya, and Tuzantlalpa. In the GIS, each ranch is represented by a north-south oriented square of $776 \mathrm{ha}$, the legally stipulated shape and size for sheep ranches. Overlap occurs because of the rudimentary surveying of the time and because ranches were not fenced (Aguilar-Robledo, 2003; Hunter and Sluyter, 2011; see also Wong et al., 2012). Agricultural semi-terraces visible in orthophotographs were digitized as polygons in the GIS. These polygons were then draped over the ranch polygons to reveal the areas of LULCC. To better track and visualize LULCC over time, the 47 ranches are divided into five date ranges (gaps between ranges reflect that no known ranches were awarded during those intervals).

The study area's reconstructed LULCC history reveals three zones of colonial rural land use. Agricultural production occupied a humid elevational zone along the footslopes. Ranching mainly occurred on steeper, higher slopes. An intermediate zone marks LULCC in which roughly 5950 ha of semi-terraces were converted to pastoralism through land granting of cropland putatively abandoned because of depopulation. Because a hectare of pasture sequesters $25.6 \mathrm{Mg}$ more SOC than a hectare of cultivated land, this LULCC increased the study area's total $\mathrm{C}$ pool by at least $152,300 \mathrm{Mg}$ (Figure 4).

\section{Discussion}

The $152,300 \mathrm{Mg}$ increase in the study area's SOC sequestration may represent a considerable underestimate, as supported by three lines of evidence. First, at the time the Spaniards established their colony, the study area had a dispersed settlement pattern, which implies that farmers were living near their terraced fields to maintain them (Evans, 1985; Gerhard, 1993; Sanders et al., 1979). Today, hillsides with scrub-covered terrace embankments are interspersed with wide swaths of bare bedrock, the result of the colonial period's demographic collapse, and erosion because of terrace abandonment, lack of maintenance, and degradation (Hunter, 2014). The semi-terraces visible on the orthophotos used to estimate the conversion of agricultural land to pasture are therefore but the remnants of a much more highly managed and extensive precolonial agricultural landscape. The $\mathrm{C}$ 


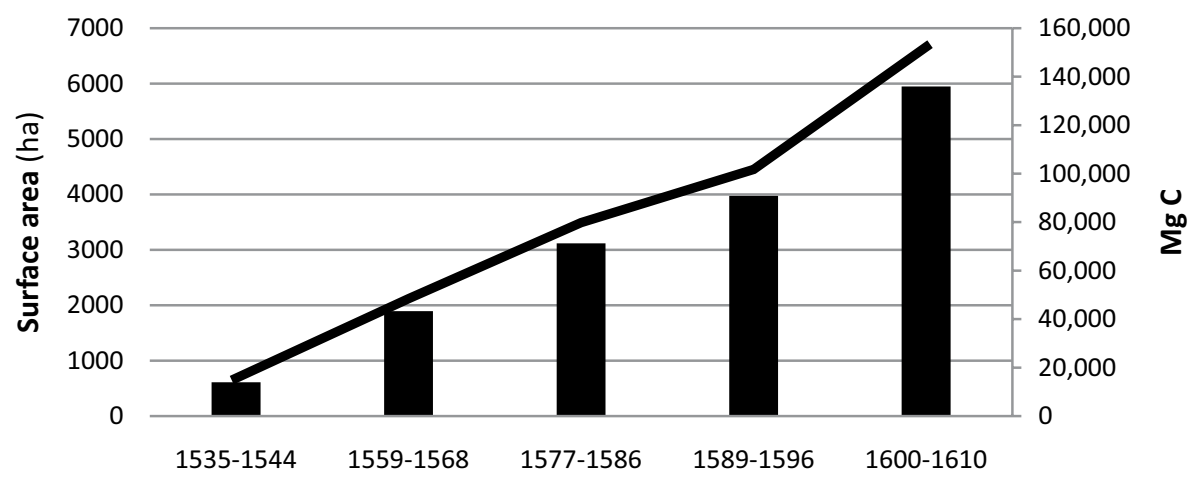

Cropland converted to pastureland

- Increase in terrestrial C pool

Figure 4. LULCC and increase in the study area's soil $C$ sequestration.

sequestered in the areas of eroded agricultural terraces would have been interred as the topsoil moved downslope and was buried under the mineral parent material that followed it soon after (Van Oost et al., 2007).

Second, just as there were more semi-terraces in the 16th century than can be mapped in the GIS, there might also have been more ranches. An unknown number of land grants might no longer be preserved in any archive, and some scholars believe that on average, at least $25 \%$ of New Spain's land grants are missing (Hunter, 2010; Prem, 1992; Simpson, 1952); others disagree (Sluyter, 2002). If true for the study region, the occurrence of more land grants and more ranches could increase the area of overlap between pasture and agricultural land used to estimate the LULCC.

Finally, because ranch boundaries did not adhere to their legally prescribed shape and size, each ranch possessed a unique shape and size that generally exceeded the prescribed square of 776 ha (Hunter, 2010). Again, the greater area of pasture could increase the area of overlap between pasture and agricultural land used to estimate the LULCC.

Global-scale vegetation models that rely on historical population density estimates and assumed per capita land use have shown large discrepancies in their calculations of LULCC and its relation to Holocene C fluxes (Boyle et al., 2011; Kaplan et al., 2011; Klein Goldewijk et al., 2011; Olofsson and Hickler, 2008; Pongratz et al., 2008). This empirical method provides a more detailed and realistic analysis of $\mathrm{C}$ sequestration at the subregional scale that can be used to refine global-scale models. Although this study's archival and cartographic method is labor and time intensive, a series of similar small-scale studies where appropriate land grant data exist would permit an informed estimate of LULCC and the historical C budgets for entire regions. Extending the finding from the study area to the entire Valle del Mezquital in simple linear fashion suggests that roughly 1.5 million $\mathrm{Mg}$ of terrestrial $\mathrm{C}$ was sequestered as a result of conversion of cropland to pastureland in the early colonial period. By using land grants to actually map LULCCs over the course of a century, this method also overcomes the problem of uncertain population density estimates and per capita land use, numbers that drive the global-scale models and explain their discrepancies (Yan et al., 2013).

\section{Conclusion}

This article contributes to a growing literature that seeks to demystify the social and environmental processes by which human societies of the past have contributed to global climate anomalies such as the 'Little Ice Age' through impacts on the $\mathrm{C}$ cycle. The method therefore potentially extends the use of such local, context-specific LULCC data further into the past, complementing sedimentary records and models based on demographic estimates. Up until this point, the major studies of this type have focused on the US Great Plains, have a time depth of $\sim 140$ years, and use detailed population and agricultural censuses to run biogeochemical simulation models of ecosystem change (Gutmann et al., 2005; Hartman et al., 2011; Parton et al., 2005, 2013). Although similar census data do not exist for colonial New Spain, this research project shows that insights into fluxes in terrestrial C stocks can nonetheless be reached using land grant data. The Spaniards awarded such land grants throughout their colonies, from California and Florida to Argentina (Sluyter, 2012). Additional LULCC reconstructions in those other areas would reduce uncertainties over pre-industrial, human-induced changes in the global C cycle (Klein Goldewijk and Verburg, 2013). These reconstructions would also clarify whether and how regionalscale LULCCs triggered global-scale climate teleconnections detectable by climate models (Pitman et al., 2009). Wider application of this paper's method would therefore provide a fuller understanding of the ecological consequences of European colonization of the Americas over the past five centuries, its LULCC consequences, and its relationship to climate change.

\section{Funding}

This research received no specific grant from any funding agency in the public, commercial, or not-for-profit sectors.

\section{References}

Aguilar-Robledo M (2003) Formation of the Miraflores Hacienda: Lands, Indians, and livestock in eastern New Spain at the end of the sixteenth century. Journal of Latin American Geography 2(1): 87-110.

Boyle JF, Gaillard M-J, Kaplan JO et al. (2011) Modelling prehistoric land use and carbon budgets: A critical review. The Holocene 21(5): 715-722.

Butzer KW (1992) Judgment or understanding?: Reflections on 1492. Queen's Quarterly: A Canadian Review 99(3): 581600.

Butzer KW (1993) No Eden in the New World. Nature 362(6415): $15-17$.

Butzer KW (1996) Ecology in the long view: Settlement histories, agrosystemic strategies, and ecological performance. Journal of Field Archaeology 23(2): 141-150.

Cook SF (1949) The Historical Demography and Ecology of the Teotlalpan (Ibero-Americana, no. 33). Berkeley, CA: University of California Press.

De Mendizábal MO (1947) Evolución económica y social del Valle del Mezquital. In: De Mendizábal (ed.) Obras Completas, vol. 6. Mexico: Mendizábal, pp. 7-195. 
Don A, Schumacher J and Freibauer A (2011) Impact of tropical land-use change on soil organic carbon stocks - A meta-analysis. Global Change Biology 17(4): 1658-1670.

Dull RA, Nevle RJ, Woods WI et al. (2010) The Columbian encounter and the Little Ice Age: Abrupt land use change, fire, and greenhouse forcing. Annals of the Association of American Geographers 100(4): 755-771.

Ellis EC (2011) Anthropogenic transformation of the terrestrial biosphere. Philosophical Transactions of the Royal Society 369(1938): 1010-1035.

Evans ST (1985) The Cerro Gordo site: A rural settlement of the Aztec period in the Basin of Mexico. Journal of Field Archaeology 12(1): 1-18.

Fournier-García P and Mondragón L (2003) Haciendas, ranchos, and the Otomí way of life in the Mezquital Valley, Hidalgo, Mexico. Ethnohistory 50(1): 47-68.

Gerhard P (1993) A Guide to the Historical Geography of New Spain. Norman, OK: University of Oklahoma Press.

Guo LB and Gifford RM (2002) Soil carbon stocks and land use change: A meta analysis. Global Change Biology 8(4): 345-360.

Gutmann MP, Parton WJ, Cunfer G et al. (2005) Population and environment in the US Great Plains. In: Entwisle B and Stern PC (eds) Population, Land Use, and Environment: Research Directions. Washington, DC: The National Academies Press, pp. 84-105.

Hartman MD, Merchant ER, Parton WJ et al. (2011) Impact of historical land-use changes on greenhouse gas exchange in the U.S. Great Plains, 1883-2003. Ecological Applications 21(4): 1105-1119.

He F, Vavrus SJ, Kutzbach JE et al. (2014) Simulating global and local surface temperature changes due to Holocene anthropogenic land cover change. Geophysical Research Letters 41(2): 623-631.

Hernández Mogica J (2000) Organización Campesina y Lucha Agraria en el Estado de Hidalgo, 1917-1940. Pachuca: UAEH.

Hoekstra R (1992) Profit from the wastelands: Social change and the formation of the haciendas in the valley of Puebla, 1570-1640. European Review of Latin American and Caribbean Studies 52: 91-123.

Houghton RA, House JI, Pongratz J et al. (2012) Carbon emissions from land use and land-cover change. Biogeosciences 9(12): 5125-5142.

Hughes JD (2001) An Environmental History of the World. London: Routledge.

Hunter R (2009) Positionality, perception, and possibility in Mexico's Valle del Mezquital. Journal of Latin American Geography 8(2): 49-69.

Hunter R (2010) Methodologies for reconstructing a pastoral landscape: Land grants in sixteenth-century New Spain. Historical Methods: A Journal of Quantitative and Interdisciplinary History 43(1): 1-13.

Hunter R (2014) Land use change in New Spain: A three-dimensional historical GIS analysis. The Professional Geographer 66(2): 260-273.

Hunter R and Sluyter A (2011) How incipient colonies create territory: The textual surveys of New Spain, 1520s-1620s. Journal of Historical Geography 37(3): 288-299.

Jaramillo VJ, Kauffman JB, Rentería-Rodríguez L et al. (2003) Biomass, carbon, and nitrogen pools in Mexican tropical dry forest landscapes. Ecosystems 6(7): 609-629.

Johnson DW (1992) Effects of forest management on soil carbon storage. Water, Air, \& Soil Pollution 64(1-2): 83-120.

Johnson K (1977) Disintegration of a traditional resource-use complex: The Otomí of the Mezquital Valley, Hidalgo, Mexico. Economic Geography 53(4): 364-367.
Kaplan JO, Krumhardt KM, Ellis EC et al. (2011) Holocene carbon emissions as a result of anthropogenic land cover change. The Holocene 21(5): 775-791.

Klein Goldewijk K and Verburg PH (2013) Uncertainties in global-scale reconstructions of historical land use: An illustration using the HYDE data set. Landscape Ecology 28(5): 861-877.

Klein Goldewijk K, Beusen A, van Drecht G et al. (2011) The HYDE 3.1 spatially explicit database of human-induced global land-use change over the past 12,000 years. Global Ecology and Biogeography 20(1): 73-86.

Konrad HW (1980) A Jesuit Hacienda in Colonial Mexico: Santa Lucia, 1576-1767. Stanford, CA: Stanford University Press.

Luchano-Constantino CA, Poggi-Varaldo HM, Del Razo LM et al. (2009) Effect of wastewater irrigation on arsenic concentration in soils and selected crops in the state of Hidalgo, Mexico. In: Bundschuh J, Armienta MA, Birkle P et al. (eds) Natural Arsenic in Groundwaters of Latin America. Leiden: CRC Press, pp. 303-310.

Mastache AG and Cobean RH (2001) Tula region. In: Webster DL and Evans ST (eds) Archaeology of Ancient Mexico. New York: Garland, pp. 777-783.

Melville EGK (1994) A Plague of Sheep: Environmental Consequences of the Conquest of Mexico. Cambridge: Cambridge University Press.

Nevle RJ and Bird DK (2008) Effects of syn-pandemic fire reduction and reforestation in the tropical Americas on atmospheric $\mathrm{CO}_{2}$ during European conquest. Palaeogeography, Palaeoclimatology, Palaeoecology 264(1-2): 25-38.

Nevle RJ, Bird DK, Ruddiman WF et al. (2011) Neotropical human-landscape interactions, fire, and atmospheric $\mathrm{CO}_{2}$ during European conquest. The Holocene 21(5): 853-864.

Nyssen J, Poesen J and Deckers J (2009) Land degradation and soil and water conservation in tropical highlands. Soil and Tillage Research 103(2): 197-202.

Olofsson J and Hickler T (2008) Effects of human land-use on the global carbon cycle during the last 6,000 years. Vegetation History and Archaeobotany 17(5): 605-615.

Ordóñez JAB, de Jong BHJ, García-Oliva F et al. (2008) Carbon content in vegetation, litter, and soil under 10 different land-use and land-cover classes in the Central Highlands of Michoacan, Mexico. Forest Ecology and Management 255(7): 2074-2084.

Ortega-Larrocea MP, Siebe C, Becard G et al. (2001) Impact of a century of wastewater irrigation on the abundance of arbuscular mycorrhizal spores in the soil of the Mezquital Valley of Mexico. Applied Soil Ecology 16(2): 149-157.

Parton WJ, Gutmann MP, Hartman MD et al. (2013) Simulating biogeochemical impacts of historical land-use change in the U.S. Great Plains from 1870-2003. In: Brown DG, Robinson DT, French NHF et al. (eds) Land Use and the Carbon Cycle: Advances in Integrated Science, Management, and Policy. Cambridge: Cambridge University Press, pp. 287-304.

Parton WJ, Gutmann MP, Williams SA et al. (2005) Ecological impact of historical land-use patterns in the Great Plains: A methodological assessment. Ecological Applications 15(6): 1915-1928.

Pitman AJ, de Noblet-Ducoudré N, Cruz FT et al. (2009) Uncertainties in climate responses to past land cover change: First results from the LUCID intercomparison study. Geophysical Research Letters 36(14): L14814.

Pongratz J, Reick C, Raddatz T et al. (2008) A reconstruction of global agricultural areas and land cover for the last millennium. Global Biogeochemical Cycles 22(3): GB3018. 
Post WM and Kwon KC (2000) Soil carbon sequestration and land-use change: Processes and potential. Global Change Biology 6(3): 317-328.

Power MJ, Mayle FE, Bartlein PJ et al. (2012) Climatic control of the biomass-burning decline in the Americas after AD 1500. The Holocene 23(1): 3-13.

Prem HJ (1992) Spanish colonization and Indian property in central Mexico, 1521-1620. Annals of the Association of American Geographers 82(3): 444-459.

Richards JF (2003) The Unending Frontier: An Environmental History of the Early Modern World. Berkeley, CA: University of California Press.

Ruddiman WF (2003) The anthropogenic greenhouse era began thousands of years ago. Climatic Change 61(3): 261-293.

Ruddiman WF, Vavrus S, Kutzbach J et al. (2014) Does preindustrial warming double the anthropogenic total? The Anthropocene Review 1(2): 147-153.

Sanders WT, Parsons JR and Santley RS (1979) The Basin of Mexico: Ecological Processes in the Evolution of a Civilization. New York: Academic Press.

Simpson LB (1952) Exploitation of Land in Central Mexico in the Sixteenth Century (Ibero-Americana, no. 36). Berkeley, CA: University of California Press.
Sluyter A (1999) The making of the myth in postcolonial development: Material-conceptual landscape transformation in sixteenth-century Veracruz. Annals of the Association of American Geographers 89(3): 377-401.

Sluyter A (2002) Colonialism and Landscape: Postcolonial Theory and Applications. New York: Rowman \& Littlefield.

Sluyter A (2012) Black Ranching Frontiers: African Cattle Herders of the Atlantic World, 1500-1900. New Haven, CT: Yale University Press.

Tortajada C and Castelán E (2003) Water management for a megacity: Mexico City metropolitan area. Ambio 32(2): 124-129.

Van Oost K, Quine TA, Govers G et al. (2007) The impact of agricultural soil erosion on the global carbon cycle. Science 318(5850): 626-629.

Wong DW, So BKL and Zhang P (2012) Addressing quality issues of historical GIS data: An example of Republican Beijing. Annals of GIS 18(1): 17-29.

Yan M, Wang Z, Kaplan JO et al. (2013) Comparison between reconstructions of global anthropogenic land cover change over past two millennia. Chinese Geographical Science 23(2): 131-146. 